eddies appear to result from the interactions of the rim current with topography and baroclinic instabilities [Oguz et al., 1993]. The surface salinity field shown in Figure $2 b$ clearly displays the regions of influence of the Danube River.

In addition to the salinity and temperature, oxygen, hydrogen sulfide, nutrients, and Secchi disk depth were measured during the HYDROBLACK '91 survey. Figure 2c shows the surface oxygen content from this survey.

Later cruises have been completed. CoMSBlack ' $92 \mathrm{a}$, conducted in July 1992 by five ships, focused on fish egg and larval surveys, as well as populations of Aurelia and Mnemiopsis throughout the Black Sea. A two-ship cruise collected water samples for the study of Chernobyl radio-tracers throughout the Black Sea in August 1992. A survey of the spring phytoplankton bloom was held in April 1993. Another cruise was planned for July 1993 to examine ichthyoplankton distribution.

The CoMSBlack field program is to be carried out over a period of at least 5 years, from 1991 to 1996, with three different types of coordinated programs planned: general surveys, process studies, and coastal seas circulation.

General Surveys: General circulation surveys will establish the overall biogeochemical framework, organism distribution and densities, biodiversity, and thermohaline characteristics, and identify and shed understanding on the dynamics of the major transport processes, such as the permanent, recurrent, and transient features of general circulation; that is, the rim current, subbasin-scale gyres, mesoscale, and sub-mesoscale eddies. The effect of cyclonic and anticyclonic flows as sources and sinks of nutrients is the primary concern of these investigations.

General survey cruises will be held biannually from 1992 to 1994 . Initial times chosen for these surveys are from September to October for the preceding phase and April for the spreading phase of the ClL. Cruises will be added or rescheduled to obtain full seasonal coverage where possible.

Process Studies: After each general survey in the spring, fine-resolution process studies will be carried out in selected subregions of the sea to investigate various interdisciplinary and disciplinary topics. For instance, physical process studies will investigate the formation of water masses by convection and/or isopycnal mixing or by generation over the shelf regions. The spreading, transformation, and transport of nutrients by CIL will be studied. The investigation of mesoscale and submesoscale structures and their interactions in relation to dispersal of nutrients and productivity will be an integral part of these process studies. The regions recommended for the process studies that have adequate resolution in clude the Northwestern Shelf region, the centers of cyclonic subbasin scales gyres, the pre-Bosphorus area, and the persistent anticyclonic flow region in the southeastern Black Sea.
Coastal Seas Circulation Dynamics and Fluxes: In this program, special attention will be given to the fine-resolution field investigations in the Black Sea shelf areas encompassing the northwestern, western, and southwestern shelves as well as the southern shelf region extending from the Bosphorus to Sinop peninsula (Figure la). The major physical processes affecting the distribution of nutrients and productivity are meandering off the rim current in the form of filaments and other coherent structures, baroclinicbarotropic instability processes, frontal processes including shelf/slope fronts, and dynamics of river plumes.

In all of the field studies described above, extensive measurements of phytoplankton and zooplankton, including fish eggs and larvae, selected benthic organisms, and the predatory species such as $M$. leidyi will be made to investigate species composi tion and abundance in relation to the nonequilibrium ecosystem of the Black Sea as affected by natural and man-induced processes.

\section{Modeling}

A modeling activity has been established to develop a new generation of community models and methodology, but activities are not centered at any specific institution. The ecological modeling group will meet for the first time in Sofia, Bulgaria, in early 1994. The group will discuss

- ecosystem models pertinent to the

Black Sea

- long-term climatic change models

- models for carrying out the eddy-resolving general circulation studies that take into account regional processes such the water mass formation

- models that investigate circulation dynamics of the coastal and shelf seas and their interactions with the open sea, which require adequate resolution and special techniques for complexities due the combined effects of stratification and rapidly varying topography, and

- a data base for initialization and intercalibration of models, including representative forcing fields of monthly mean wind stress, heat flux, evaporation, and precipitation, as well as river discharge and inflows/outflows through the straits.

CoMSBlack seeks collaboration with all interested scientific groups. It hopes to facilitate inclusion of other aspects of oceanography into the ongoing studies, to expand on the already broad activities of the current member institutions and member states.

\section{Acknowledgments}

CoMSBlack has required the full participation of the governments of the various Black Sea riparian countries, as well as external sponsors. Too numerous to name in full, we would like to identify the academies of science in Bulgaria, Romania, Russia, Ukraine, and the United States, as well as the TUBITAK and NATO Science for Stability Program in Turkey, the Intergovernmental Oceanographic Commission, the National Science Foundation, and the Office of Naval Research (London). Significant private contributors to this effort include the Regional Environmental Center for Central and Eastern Europe, the Andrew W. Mellon Foundation, the Woods Hole Oceanographic Institution (through its director, Craig Dorman), and various private donors energized through the efforts of Rodney Berens of New York.

\section{References}

Aubrey, D. G. (Ed.), Country profiles and working group reports, IOC/MRI Tech. Rep., IOC/MRI, Paris, in press, 1993a

Aubrey, D. G. (Ed.), Working group reports, $I O C /$ MRI Tech. Rep., IOC/MRI, Paris, in press, 1993b. Aubrey, D. G., T. Oguz, E. Demirov, V. Ivanov, T. McSherry, V. Diaconu, and E. Nikolaenko, HY. DROBLACK ' 91 report of the CTD intercalibration workshop, WHOI 92-10/CRC 92-01, CoMSBlack 92-005, Woods Hole Oceanographic Institution, Woods Hole, Mass., 1992.

Blatov, A. S., A. N. Kosarev, and V. S. Tuzhilkin, Variability of the hydrographic structure of the Black Sea water and its links with external factors (in Russian), Vodnyye Resursy, 6, 71, 1984

Moncheva, S., Blooming and succession of phyto plankton under eutrophication conditions (in Bulgarian), Proc. First National Conference on Ecological Monitoring, Plovdiv, pp. 133-138, 1987.

Murray, J. W., Black Sea Oceanography: Results from the 1988 Black Sea Expedition, Deep Sea Res., 38, Suppl. 2, 1991.

Oguz, T., D. G. Aubrey, V. S. Latun, E. Demirov, L. Koveshnikov, H. I. Sur, V. Diaconu, S. Besiktepe M. Duman, R. Limeburner, and V. Eremeev, Mesoscale circulation and thermohaline structure of the Black Sea observed during Hydroblack 1991, Deep Sea Res., in press, 1993.

Ozsoy, E. A. Hecht, and Ü. Ünlüata Circulation and hydrography of the Levantine Basin: Results of the POEM coordinated experiments 19851986, Prog. Oceanogr. 22, 125, 1989.

\title{
Paleoceanographic Record of North Pacific Quantified
}

\section{Leg 145 Scientific Party}

After a 21-year absence, scientific drilling returned to the high latitudes of the north Pacific from July to September 1992 (Figure 1). The main objectives of the Ocean Drilling Program's Leg 145 were to collect high-reso- lution records of Miocene to Quaternary changes in ocean circulation, biological activity, and global climate, and to recover high-latitude Paleogene and Cretaceous carbonate-bearing sediments to help decipher 
the oceanographic record of the old Northern Hemisphere Pacific.

To study the history of water masses and a site on the Meiji Tongue that had been proposed to represent a north-Atlantic type of drift deposit [Scholl et al., 1977; Mammerickx, 1985], drilling of a depth transect down the flanks of Detroit Seamount, a large seamount near the northern end of the Emperor Seamount chain, was planned. To achieve these goals, the JOIDES Resolution drilled twenty-five holes at seven sites at four locations (Figure 1, Table 1). New, more aggressive coring techniques evolved at Site 881, the first drill site, that allowed the recovery of long, essentially undisturbed sedimentary sections. These sections enabled us to construct long paleomagnetic reversal stratigraphies, which permitted a refined calibration of the diatom-based biostratigraphy used at every site.

Basalt was recovered at the base of the sedimentary section at three of the four general drilling locations. Extensive logging operations were conducted at four of the drill sites and included the first ODP deployment of the French magnetometer and susceptibility tools. Overall sediment and rock recovery totaled $4321 \mathrm{~m}, 87 \%$ of the cored section.

This amount of recovery places Leg 145 among only five cruises in the history of the ODP and its predecessor, the Deep Sea Drilling Project, that have recovered more than 4 $\mathrm{km}$ of material.

All sediments recovered by Leg 145 showed a similar stratigraphy (Figure 2). The uppermost unit is a siliciclastic and ash-rich diatom ooze of late Pliocene to Pleistocene age, which reflects paleoceanic and paleoclimatic conditions in the north Pacific that correspond to Northern Hemisphere glaciation. A nearly pure diatom ooze of Miocene to late Pliocene age underlies the upper clayey ooze unit. Beneath the Miocene siliceous oozes at the Detroit Seamount sites are calcareous sediments of Oligocene and Eocene age and some uppermost $\mathrm{Pa}$ leocene(?) to middle Eocene ashes. At Site $885 / 886$, beneath the low-productivity central north Pacific, the middle Cenozoic and older sediments are the chocolate brown pelagic clays characteristic of the deep ocean.

\section{Important Changes at $2.6 \mathrm{Ma}$}

Important changes in the sedimentary record occur in conjunction with the onset of major Northern Hemisphere glaciation at $2.6 \mathrm{Ma}$ (time scale of Cande and Kent [1992]; Figure 3). Drilling at Site 881 documented the beginning of the abyssal reworking that now redistributes abyssal sediment in this region [Damuth et al., 1983] at 2.6 $\mathrm{Ma}$. One consequence of this Plio-Pleistocene reworking is that sedimentation rates are higher at the deeper sites. There was a several-fold increase in the deposition rate of

Direct correspondence to David Rea, Department of Geological Sciences, University of Michigan, 1006 C. C. Little Building, Ann Arbor, MI 481091063

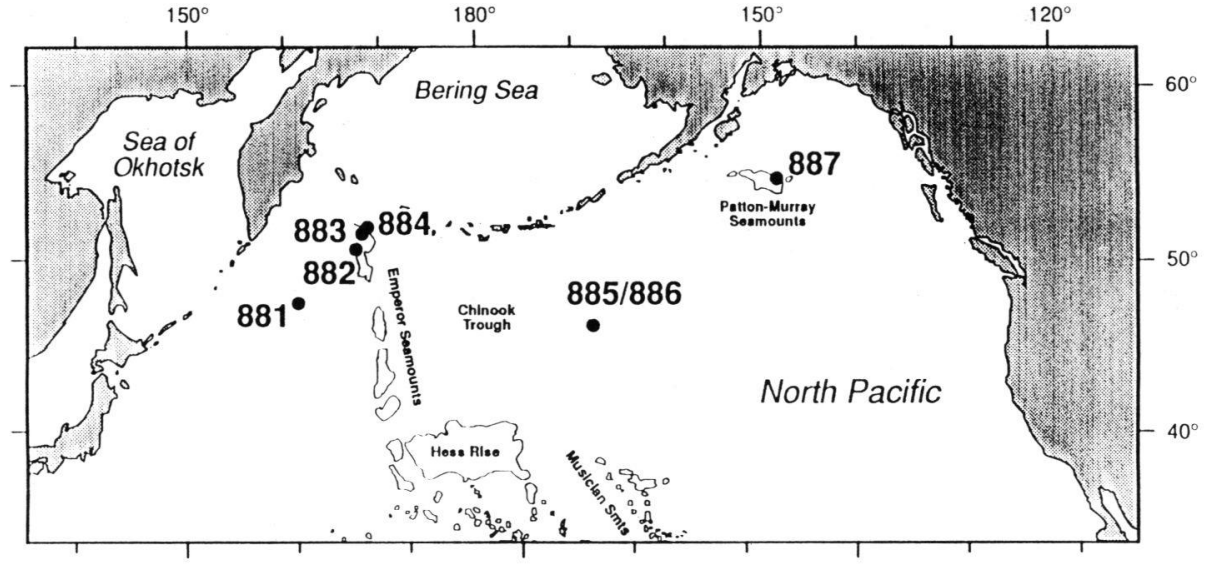

Fig. 1. Index map of the north Pacific Ocean showing locations of Leg 145 drill sites.
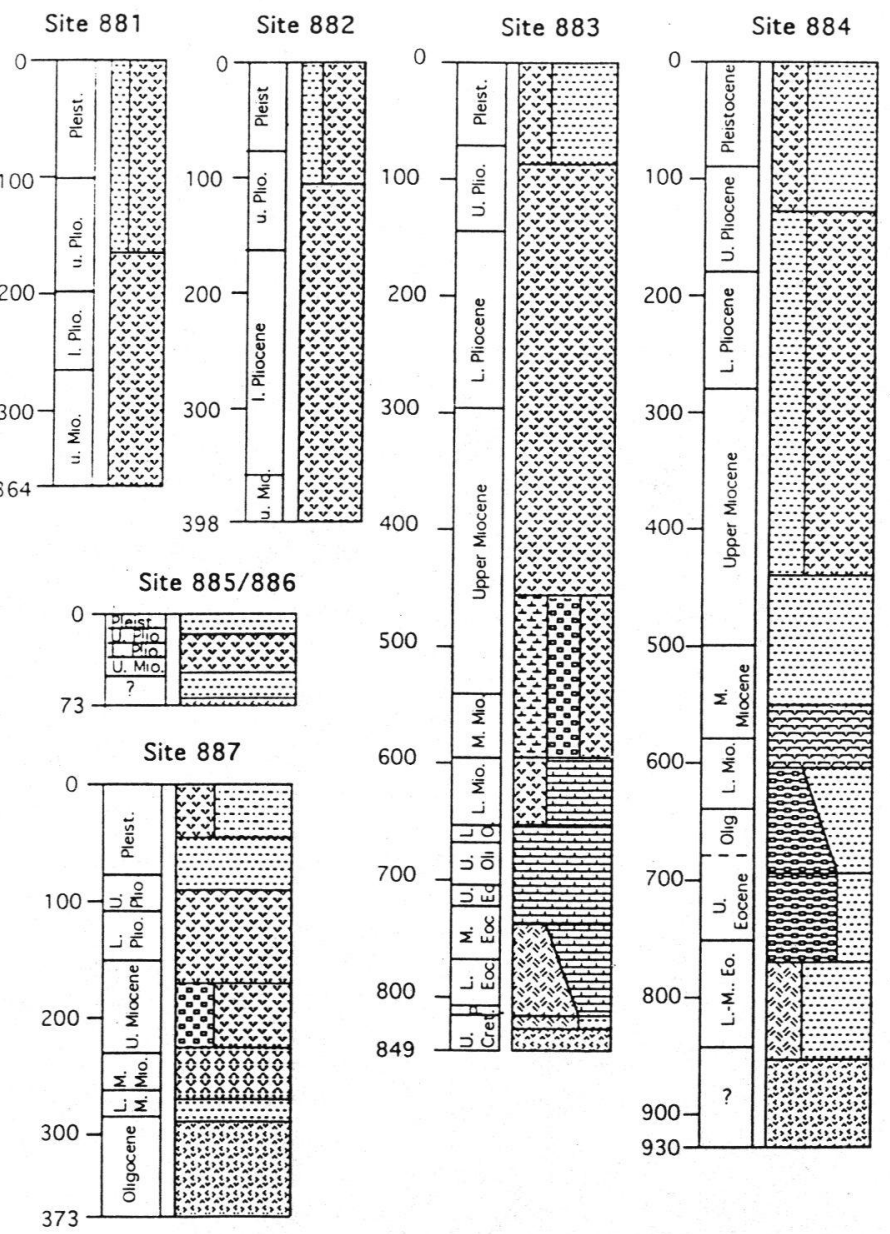

Fig. 2. Lithology and age of sediments recovered on Leg 145. Symbols are dashes, silt, and clay; $v$, siliceous ooze; rectangles and brick patterns, carbonates; alternating diagonal hash marks, ash; lowermost blotchy pattern, basalt. hemipelagic quartz and clay after $2.6 \mathrm{Ma}$, according to a record of the physical weathering and erosion of Siberia and Alaska.

Less important in terms of total mass, but especially valuable as paleoclimatic indicators, are the occurrences of glacial dropstones-stones dropped from melting icebergs. Leg 145 demonstrated that dropstones appear in abundance at 2.6 Ma (Figure 3), signaling the onset of large-scale glaciation in Siberia and Alaska at that time. There is a noticeable decline in the number and flux of dropstones both north and south away from a maximum centered near the northern entrance from the Sea of Okhotsk to the $\mathrm{Pa}$ - cific. The main source of dropstones may have been Siberia via the Sea of Okhotsk and/or the southern portion of the Kamchatka Peninsula. Drilling at Site 887 recovered dropstones of North American provenance in far greater abundance than Siberian dropstones of the northwest Pacific.

The mass accumulation rate of windblown dust to the deep sea provides a record of source area climate [Rea et al., 1985 ]. At sites $885 / 886$, expressly planned to recover the Cenozoic eolian record, there is a five-fold increase in the dust flux in sediments younger than $2.6 \mathrm{Ma}$. The mineralogy of these terrigenous materials can be linked 
to the loess deposits of China and the sudden increase in the dust flux records loess deposition that began in conjunction with the onset of Northern Hemisphere glaciation.

Another distinctive event that occurred at $2.6 \mathrm{Ma}$ is an order of magnitude increase in the number and volume of ash beds (Figure 3). This late Cenozoic volcanic event dwarfs any earlier ash eruptions in the Miocene or Eocene portions of the section. The onset of significant volcanic activity precedes the late Pliocene dropstone deposition by $40-50 \mathrm{kyr}$ in the northwest Pacific and by perhaps 400 kyr in the Gulf of Alaska, downwind from the central and eastern Aleutians. The sudden change in ash abundance and its stratigraphic relationship to the dropstones is so striking that it may be prudent to reconsider the effect of these many eruptions on Northern Hemisphere climates.

\section{Tertiary Paleoceanography and Paleoclimatology}

During the middle and late Miocene, the ocean deep-circulation system underwent reorganization toward becoming more like the modern pattern. The north Atlantic became an important source of deep water; it eventually ends up in the north Pacific, where it rises to the surface and begins the return journey to the Atlantic. These deep waters bring to the north Pacific all the chemical species that have been dissolving in them, including nutrients, especially silica, and dissolved organic carbon and $\mathrm{CO}_{2}$. The paleoceanographic record of this chemical delivery to the north Pacific should be recorded by enhanced biological productivity, especially of siliceous organisms, by enhanced dissolution of calcium carbonate and by more ${ }^{12} \mathrm{C}$-enriched carbon isotopic values in benthic foraminifers. We hoped to quantify the mass flux of opal to the floor of the North Pacific and thus better define the nature of the "silica shift" [Keller and Barron, 1983], decipher the record of carbonate deposition, and collect the appropriate samples for analysis of the carbon isotope signature of the water masses.

During the middle and earlier portion of the late Miocene, opal was deposited at rates of $20-40 \mathrm{~m} / \mathrm{m}$.y. in the northwest Pacific and 8-15 m/m.y. in the Gulf of Alaska. Extreme rates of diatom deposition occur during the latest Miocene and early Pliocene, roughly 6-3 Ma (Figure 3 ). During this period, the flux of silica increased several fold, denoting very high biological productivity. Sedimentation rates may have far exceeded $100 \mathrm{~m} / \mathrm{m} . \mathrm{y}$. in the northwest Pacific for portions of this period. Similar high rates of biogenic sedimentation have been documented in the equatorial Pacific, Indian, Atlantic, and Southern oceans. The recognition of a global productivity maximum centered on early Pliocene time is a new and important result for paleoceanography.

At the same time that the flux of opal began to increase in the middle Miocene, the intermediate-depth waters near Detroit Seamount became more corrosive to calcium carbonate. In most of the world's

Late Cenozoic Changes in the North Pacific: Results of Leg 145

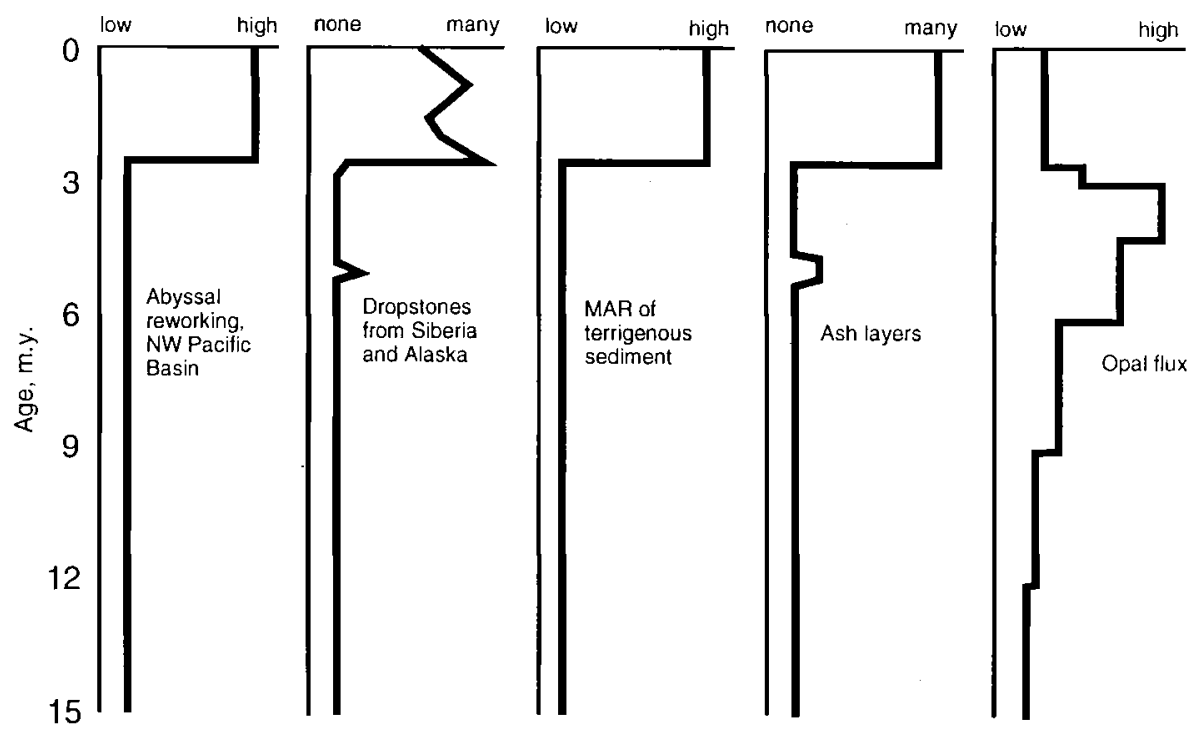

Fig. 3. Major changes in the late Cenozoic sedimentary record of the north Pacific Ocean.

oceans, the calcite compensation depth (CCD) became deeper during the last 12-15 m.y. [van Andel, 1975]. Leg 145 results demonstrate just the opposite in the North Pacific. Here the CCD became $1500 \mathrm{~m}$ shallower since the early Miocene (Figure 4). This effect was confined to latitudes north of $40^{\circ} \mathrm{N}$ and was most likely the result of the same change in ocean circulation that increased the supply of silica and other nutrients to the north Pacific in the middle Miocene. The CCD at Detroit Seamount, at about $2400 \mathrm{~m}$ depth, is now $2 \mathrm{~km}$ shallower than on the Hess and Shatsky rises only $10^{\circ}$ to the south, a good example of CCD shoaling toward regions of high silica productivity.

An important aspect of the Paleogene record from Detroit Seamount is a history of downslope reworking and slumping of sediments. Much of this activity, preserved as debris flows (including matrix-supported angular clasts of soft chalk), as recumbent folds, and as turbidites occurred during the middle and later part of the Eocene. This northern Pacific reworking episode matches in time that suggested for the central and western Pacific, based on DSDP drilling [Thiede, 1981]. None of the reworked materials contains any reefal or shallow-water debris, indicating that Detroit Seamount was never at sea level.

\section{Igneous Basement}

Basalt was recovered from Detroit Seamount at sites 883 and 884, from Patton-Murray Seamount platform at Site 887 , and from the central north Pacific at Site 885/886. Basalts from the seamounts should reveal the ages of those features and add to our information about the petrologic and geochemical history of the respective hotspot sources. On-board paleomagnetic results suggest a paleolatitude of seamount emplacement of

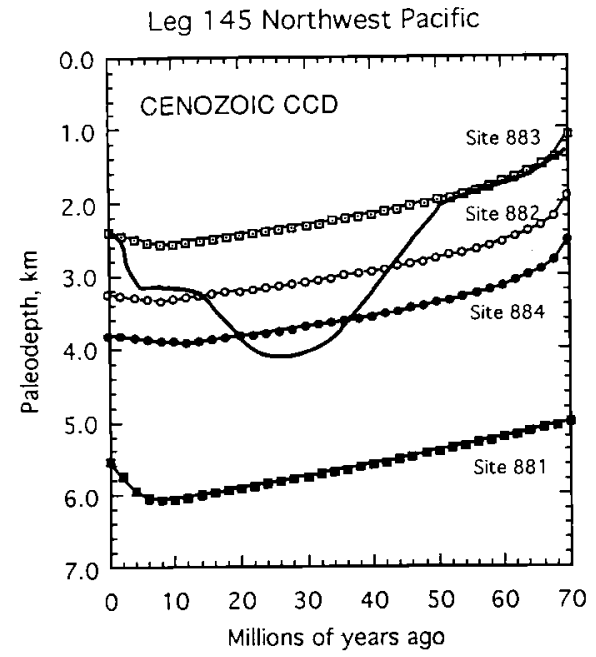

Fig. 4. Subsidence curves for the Leg 145 sites in the northwestern Pacific and the level of the $C C D$.

about $33^{\circ}$ for Detroit Seamount, about $13^{\circ}$ north of the present location of the Hawaiian hotspot. The basalt from sites $885 / 886$ occurred in an unexpected stratigraphic setting. The Cretaceous carbonates that underlie the sedimentary section in the north Pacific were absent and only about $18 \mathrm{~m}$ of clay were recovered between the Miocene siliceous oozes and the highly altered, microcrystalline, yellow-orange weathered basalt. Geochemical analysis and, if possible, dating of these rocks may help to determine if we encountered a flow or sill, and thus reveal new information about volcanic rejuvenation of the north-central Pacific Ocean.

\section{The Meiji Drift}

The Meiji Tongue lies along the northeast side of the northernmost Emperor Seamount chain and is over $1000 \mathrm{~km}$ long, about 350 $\mathrm{km}$ wide, and up to $1800 \mathrm{~m}$ thick at its 
northwestern end at the Kamchatka Strait. At Site 884, the deposit consists of a mixture of pelagic material, mostly diatom ooze and occasionally nannofossil chalk, and hemipelagic clay and quartz. Sediments are generally homogenous, display almost no sedimentary structures, and have accumulated at high rates of many tens of meters per million years. The mineralogy of the terrigenous component is constant through the entire $700 \mathrm{~m}$ of the deposit and reflects a Siberian source [Scholl et al., 1977]. Furthermore, the deposit contains an Arctic, benthic, diatom flora that occurs only on the shallow waters of Siberia and the Aleutians. These northern source diatoms and minerals characterize the sediments back through the Oligocene and indicate an apparently continuous depositional process with a northerly source.

The early Oligocene onset and continuing deposition of the Meiji Drift entails important consequences to the physical oceanography of the north Pacific. Southerly flow of bottom waters from the Bering Sea into the north Pacific basin has been occurring for as long as 35 m.y. This flow has been controlled geographically by the location of one or two deep passages through the Aleutian Ridge and by the existence of a northwest continuation of the Emperor Seamount chain. At present, the deep passage is the Kamchatka Strait. Water moves south at all depths through this strait at rates varying seasonally from less than 10 to more than 20 sverdrup [Arsenjev, 1967; Verkhunov and Tkachenko, 1992]

\section{Summary}

ODP Leg 145 recovered materials that will permit quantification of the paleoceanographic record of the north Pacific, a critically important region for the Cenozoic record of ocean circulation. Shipboard results show a new and dynamic picture of this region. The north Pacific was affected by the apparently basin-wide reworking episode that characterizes shallow and mid-depth Eocene sections elsewhere. Deep waters emanating from the Bering Sea have been moving south along the northwest flank of the Emperor Seamounts since at least early Oligocene time. We documented the middle Miocene onset and a latest Miocene and early Pliocene maximum of silica deposition and coeval shoaling of the CCD by about $1500 \mathrm{~m}$ to its present depth of about $2400 \mathrm{~m}$.

Numerous changes occur at $2.6 \mathrm{Ma}$, the time of significant ice-volume buildup in the Northern Hemisphere. Abyssal circulation in the northwestern Pacific became vigorous enough to redistribute sediments, a process which continues today. The influx of all kinds of continental materials increases enormously at $2.6 \mathrm{Ma}$ : dropstones become important and are most abundant in sites seaward from the Sea of Ohktosk (Site 881) and in the Gulf of Alaska (Site 887), the flux of hemipelagic and eolian sediments to the ocean increases several fold, and there is an enormous increase in volcanic activity, unmatched by any found earlier in the Miocene through lower Pliocene record.

\section{Leg 145 Scientific Party}

David Rea and Ivan Basov (co-chief scientists), Thomas Janecek (staff scientist), Eve Arnold, John Barron, Luc Beaufort, James Bristow, Peter deMenocal, Gilles Dubuisson, Andrey Gladenkov, Tark Hamilton, Lynn Ingram, Lloyd Keigwin, Randall Keller, Aarno Kotilainen, Lawrence Krissek, Barrie McKelvie, Joseph Morley, Makoto Okada, Gunnar Olafsson, Robert Owen, Dorothy Pak, Thomas Pedersen, John Roberts, Anne Rutledge, Valery Shilov, Hilde Snoeckx, Rainer Stax, Ralf Tiedemann, and Robin Weeks

\section{References}

Arsenjev, V. S., Currents and Water Masses of the Bering Sea (in Russian), Nauka Publishing House, Moscow, 133 pp., 1967.

Cande, S. C., and D. V. Kent, A new geomagnetic polarity time scale for Late Cretaceous and Cen. ozoic, J. Geophys. Res., 97, 13,917, 1992.

Damuth, J. E., R. D. Jacobi, and D. E. Hayes, Sedimentation processes in the northwest Pacific Basin revealed by the echo-character mapping studies, Geol. Soc. Am. Bull., 94, 381, 1983.

Keller, G., and J. A. Barron, Paleoceanographic implication of Miocene deep-sea hiatuses, $\mathrm{Ceol}$ Soc. Am. Bull, 94, 590, 1983.

Mammerickx, J., A deep-sea thermohaline flow path in the northwest Pacific, Mar. Geol., 65, 1, 1985

Rea, D. K., M. Leinen, and T. R. Janecek, A geological approach to the long term history of atmospheric circulation, Science, 227, 21, 1985.

Scholl, D. V., J. R. Hein, M. Marlow, and E. C. Buffington, Meiji sediment tongue: North Pacific evidence for limited movement between the $\mathrm{Pa}$ cific and North American plates, Geol. Soc. Am. Bull., 88, 1567, 1977.

Thiede, J., Reworked neritic fossils in upper Meso zoic and Cenozoic central Pacific deep sea sediments monitor sea-level changes, Science, 211 , 1422,1981

van Andel, T. H., Mesozoic/Cenozoic calcite compensation depth and the global distribution of calcareous sediments, Earth Planet. Sci. Lett., 26 187, 1975.

Verkhunov, A. V., and Y. Y. Tkachenko, Recent observations of variability in the western Bering Sea current system, J. Geophys. Res., 97, 14,369, 1992.

\section{Hurricane Season Prediction Updated}

\section{PAGES 401-402}

As he has done for about the last 10 years, William Gray of Colorado State University in Fort Collins has forecast this year's tropical cyclone activity for the Atlantic basin, based on meteorological data for June and July. Updating his June 4 and November 24 predictions, which called for more intense activity, Gray has predicted a generally average hurricane season, compared with hurricane activity over the last 4 decades. Hurricane Emily, which brushed North Carolina's Outer Banks on August 31, is the first of six Atlantic Basin hurricanes predicted by Gray.

According to Gray, in addition to the six hurricanes, this season should see ten named storms of at least tropical storm intensity, about twenty-five hurricane days, a total of fifty named storm days, and a Hurricane Destruction Potential of 55 (HDP mea- sures a hurricane's potential for wind and storm surge destruction, defined as the sum of the square of a hurricane's maximum wind speed for each 6-hour period of its duration).

Gray released his most recent forecast on August 5 and will issue a verification of this forecast in late November. His past predictions have been fairly accurate, and the late July forecasts have been more on target than the early June forecasts. According to Gray, this season has been one of the most difficult forecasts because of the uncertainty concerning the unexpected resurgence of warm El Niño conditions in April-June. At the time of Gray's June 4 forecast, he did not believe that these warm conditions would persist through the height of the 1993 season from mid-August through mid-October.

Gray bases his forecast on regional-scale factors that he and colleagues have previously shown to be statistically related to seasonal variations of hurricane activity. Values of these factors are available by late November of the previous year, or by early June, at the official start of the hurricane season, or by early August, just before the start of the most active portion of the hurricane season.

For early August, the predictive factors include the direction of the east-west stratospheric Quasi-Biennial Oscillation (QBO) winds that circle the globe above the equa tor. During the 1993 season, these QBO winds will be westerly, causing this year's hurricane activity to intensify, said Gray.

The stronger upper tropospheric westerly winds that occur over the Caribbean basin and western Atlantic during El Niño (warm water) seasons play a role in Gray's predic tion. Atlantic hurricane seasons during mod erate or strong El Niño events average only about $40 \%$ as much hurricane activity as occurs during non-El Nin̄o seasons. Above average amounts of hurricane activity have been associated with cold water.

Gray also figures the amount of rainfall during June-July in the Western Sahel region of western Africa into his forecast. Because rainfall is expected to be below average there again this year, Gray anticipates that there will be only two intense or major hurricanes (Saffir/Simpson intensity category 3, 4, or 5 this season on a scale of 1-5).

The sea-level pressure anomaly on the eastern Caribbean basin is another factor that Gray examines. Negative pressure anomalies in late spring and early summer are typically associated with active hurricane seasons, and vice-versa. Pressure anomaly values for June and July of this year have been near normal and are not expected to have much influence on this season's hurricane activity.

Gray is quick to point out the limitations of his seasonal forecast. He notes that his prediction is a statistical scheme that will fail in some years. It does not specifically predict where in the Atlantic basin the storms will strike, nor when, he says. Even if 1993 proves to be below average in hurricane activity, hurricanes may still strike along the U.S. or Caribbean coastline. Or, in the event that 1993 proves to be a very active 